\title{
Vegetative and reproductive morphology of Kallymenia patens (Kallymeniaceae, Rhodophyta) in the Mediterranean Sea
}

\author{
Alba Vergés* and Conxi Rodríguez-Prieto \\ University of Girona, Faculty of Sciences, Department \\ of Environmental Sciences, Campus de Montilivi, 17071 \\ Girona, Spain, e-mail: alba.verges@udg.es \\ * Corresponding author
}

\begin{abstract}
Reproductive morphology of the Mediterranean red alga Kallymenia patens is described for the first time, confirming its position in the genus. K. patens is characterized by a non-procarpic female reproductive apparatus, carpogonial branch systems consisting of supporting cells bearing both three-celled carpogonial branches and subsidiary cells that lack a hypogynous cell and carpogonium; fusion cells develop numerous connecting filaments, and tetrasporangia are scattered over the thallus and are probably cruciately divided. Old fertile spathulate specimens of $K$. patens are morphologically similar to $K$. spathulata, but they can be distinguished by the length of spathulated proliferations (up to $0.6 \mathrm{~cm}$ and $6 \mathrm{~cm}$, respectively), the length of inner cortical cells (up to 70 and $30 \mu \mathrm{m}$, respectively), and the gonimoblast location (in proliferations from the perennial part of the blade and over all the thallus surface, respectively).
\end{abstract}

Keywords: Kallymenia patens; Kallymeniaceae; reproduction; Rhodophyta; taxonomy.

\section{Introduction}

The genus Kallymenia J. Agardh (Kallymeniaceae, Rhodophyta) is currently represented in the Mediterranean Sea by the type species, K. reniformis (Turner) J. Agardh (1842), and also by K. feldmannii Codomier (1971), K. lacerata Feldmann (1942), K. requienii (J. Agardh) J. Agardh (1842), K. patens (J. Agardh) Codomier ex Parkinson (1980) and K. spathulata (J. Agardh) Codomier ex Parkinson (1980) (Codomier 1968, 1971, 1972, Rodríguez-Prieto and Vergés 2001, Vergés 2001, Vergés and Rodríguez-Prieto 2006). K. patens, a species originally described as Halymenia patens J. Agardh (1851), and later changed to the genus Halarachnion (J. Agardh) DeToni (1905), was established in the genus Kallymenia by Codomier (1971). However, it was Parkinson (1980) who validly published the new combination, Kallymenia patens (J. Agardh) Codomier ex Parkinson.

Male and female reproductive structures of Kallymenia patens are unknown, and it has been considered a member of the genus Kallymenia due only to its morphology and vegetative structures, which are similar to those of the type species, $K$. reniformis. It has: (i) a flattened thallus, (ii) a multiaxial structure, (iii) a cortex of several cell layers diminishing in size outwardly, and (iv) a medulla composed of filaments intermixed with ganglionic stellate cells (Codomier 1968, 1971, 1972, Vergés 2001). Tetrasporangia were found by Codomier (1978), although he did not describe them.

In the present paper, a study of some specimens of Kallymenia patens from the Mediterranean coasts of Spain and France has allowed us to describe the female reproductive structures, the postfertilization stages and the tetrasporophyte of this species, as well as to complete the description of its vegetative morphology.

\section{Materials and methods}

\section{General}

Fresh specimens, collected by SCUBA or with fishing nets between December 1994 and May 2004 on the coasts of the western Mediterranean Sea (Spain and France), were examined, as were dried herbarium specimens housed at H, LD and VAB-A (included in VAL). Herbarium abbreviations follow Holmgren et al. (1990). Sections were made with a razor blade and stained subsequently in an acidified $1 \%$ aniline-blue/distilled water solution and mounted permanently in $50 \%$ Karo ${ }^{\circledR}$ corn syrup (Bestfoods, Englewood Clifts, USA). Photographs of the habits were taken with a Nikon Coolpix 3200 camera (Nikon, Tokyo, Japan); photomicrographs were taken with a Spot Insight digital camera (Diagnostic Instruments, Sterling Heights, USA) attached to an Axioskop 2 plus microscope (Zeiss, Berlin, Germany). Voucher specimens were deposited in $\mathrm{HGl}$ algae sections with reference letters HGI-A.

\section{Representative specimens examined}

Spain Cap de Creus (C. Rodríguez-Prieto, 20 June 1996, 30-35 m depth, HGI-A 4045 sterile); Palamós, Formigues Islands (C. Rodríguez-Prieto, 17 May 1998, 35 m depth, HGI-A 4044 sterile; 24 May 1998, 35 m depth, HGI-A 4787 sterile; 13 June 1999, 30-35 m depth, HGIA 4751 sterile; 20 June 1999, 30-35 m depth, HGI-A 4749 tetrasporophyte $(\oplus)$, 4754 sterile; 27 June 1999, 30 m depth, HGI-A 4750 sterile, 4752 sterile, 4753 sterile; 18 June 2000, 30 m depth, HGI-A 4776 sterile; 6 May 2001, 34 m depth, HGI-A 5266 sterile); Medes Islands, Carall Bernat (C. Rodríguez-Prieto and A. Vergés, 10 July 1998, 30 m depth, HGI-A 4047 sterile); Begur, Ses Negres (C. Rodríguez-Prieto, 3 August 1999, 27 m depth, HGI-A 4755 sterile). Balearic Islands, Minorca channel (E. Ballesteros and N. Sant, 28 December 1994, 71 m depth, HGI-A 2801 sterile, 4516 sterile; S. Mallol, 30 August 
2003, 84 m depth, HGI-A 6451 sterile); Balearic Islands, Formentera Island (E. Ballesteros, 9 May 2004, $59 \mathrm{~m}$ depth, HGI-A 6465 sterile, 6468 female gametophyte ( $q$ ), 6469 , 6470 , 6524 q, 6525 sterile, 6526 sterile, 6527 sterile, 6528 +, 6529 \%, 6530 sterile, 6531 sterile); Columbretes Islands, La Ferrera (F. Boisset, 7 July 1985, 20-25 m depth, VAB-A 462 sterile); Placer de la Barra Alta (E. Ballesteros, 23 June 1996, 20 m depth, HGI-A 4046 sterile, 4048 sterile, 4063 sterile); Columbrete Grande (F. Boisset, 18 September 1998, 15 m depth, VAB-A 1975 sterile).

France Banyuls-sur-Mer (C. Rodríguez-Prieto, 17 July 1992, 25 m depth, HGI-A 4043 sterile; July 1995, 20-25 m depth, HGl-A 4043 sterile); Corsica, Scandola (E. Ballesteros, 8 October 2004, 30 m depth, HGI-A 6602 sterile).

\section{Results}

\section{Kallymenia patens (J. Agardh) Codomier ex Parkinson (1980: 16) (Figures 1-17)}

Type locality Marseille, France.

Distribution Western Mediterranean Sea (RodríguezPrieto and Vergés 2001)

Habitat and seasonality Kallymenia patens is perennial, occurring on coralligenous bed bottoms of the circalittoral zone, usually with Rhodymenia ardissonei J. Feldmann, and in the infralittoral zone, on the rhizomes of Posidonia oceanica (Linnaeus) Delile. K. patens is present year-round, although fertile female specimens

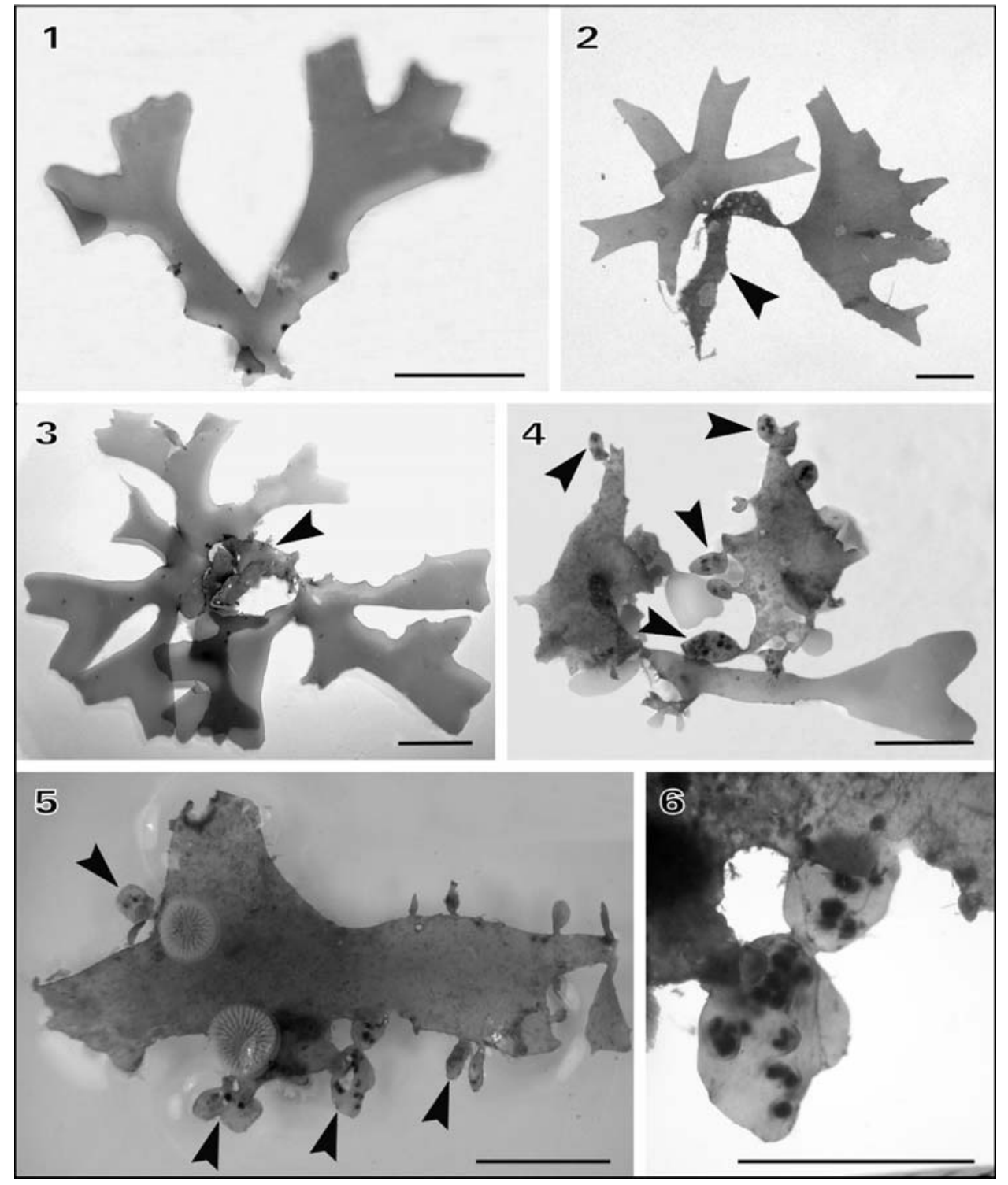

Figures 1-6 Kallymenia patens.

(1) Habit of a young individual (HGl-A 6526). (2-3) Habit of adult specimens developing new blades on perennial part (arrowhead) (HGI-A 2801, 6465). (4-5) Habit of female gametophytes bearing spathulated proliferations (arrowheads) with gonimoblasts (HGI-A 6524,6470 ). (6) Detail of thallus proliferations with several gonimoblasts (HGI-A 6470). Scale bars $=1 \mathrm{~cm}$ (Figures $1-5$ ), $5 \mathrm{~mm}$ (Figure 6). 


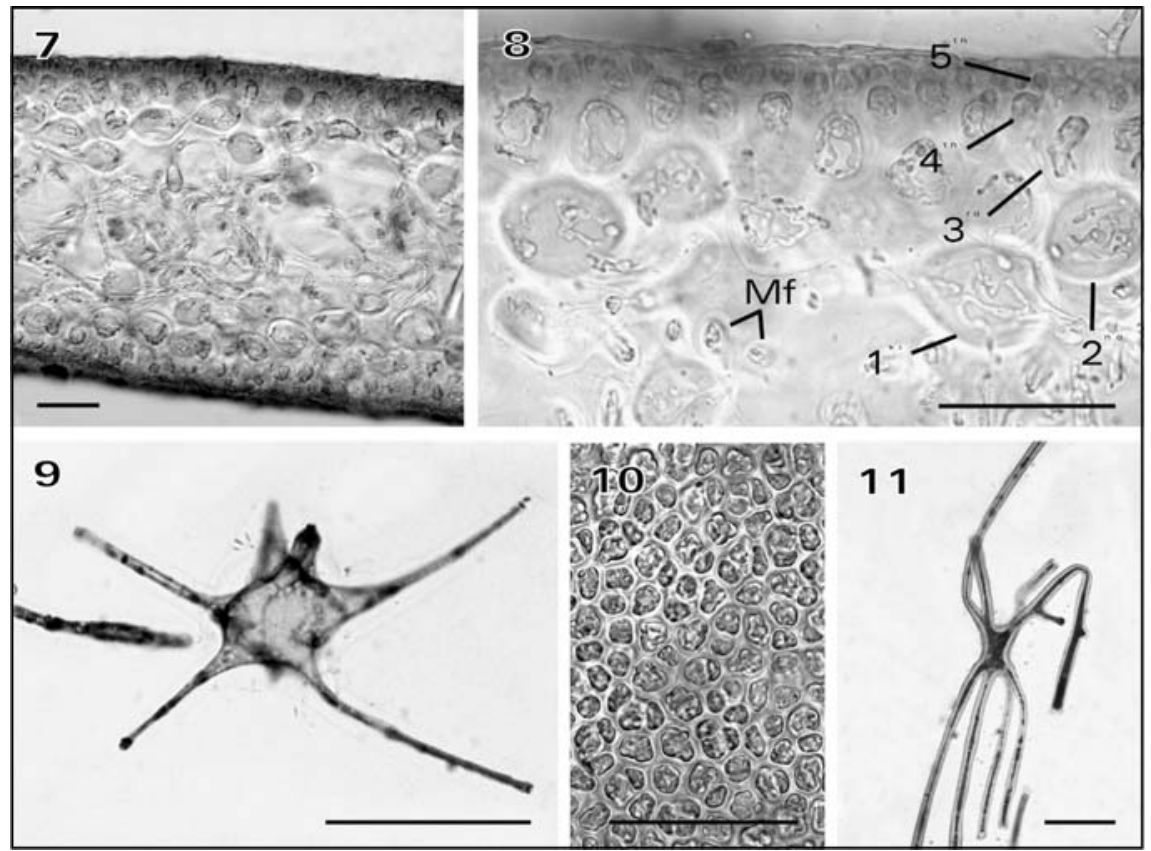

Figures 7-11 Kallymenia patens.

(7-8) Cross sections of the blade (Mf, medullary filament; 1st, 2nd, 3rd, 4th, 5th cortical layer arrangement) (HGI-A 6465, HGI-A 6451). (9) Stellate cell of the first cortical layer of cells (HGI-A 6451). (10) Outer cortical cells (surface view). (11) Medullary stellate cell (HGl-A 6451). Scale bars $=50 \mu \mathrm{m}$ (Figures 7-11).

were found only in May and tetrasporophytes were collected only in January (Codomier 1978) and June.

Habit Fronds are compressed to flattened, $<10 \mathrm{~cm}$ long, $<10 \mathrm{~cm}$ wide and 150-250 $\mu \mathrm{m}$ thick, decumbent, sessile, arising from a small discoid holdfast, pseudodichotomously or trichotomously divided and with bifurcated apices (Figures 1-4). The thallus has a basal perennial part that is more or less whole, irregularly shaped, and develops small spathulate proliferations in fertile female specimens (Figures 4-6). Blades are membranous to cartilaginous, pink to red when young, and brownish or whitish in colour when adult. Adult fronds anastomose among themselves, or do so with other thalli of the same or different species.

Vegetative structure The structure is multiaxial, with a cortex made up of five layers of cells decreasing progressively in size, changing in shape and becoming more deeply pigmented towards the thallus surface (Figures $7-8)$. Inner cortical cells (cells of the first layer) are stellate, with an ovoid cell body ( $<70 \mu \mathrm{m}$ in diameter) and radial arms situated mainly in the plane of flattening (Figures 8-9). These cells are connected by secondary pit connections, forming a network parallel to the surface of the frond and they can also be connected to medullary filaments. Cells of the second layer of cortical cells are slightly stellate and irregular or ovoid in shape $(<70 \mu \mathrm{m}$ in diameter). They are connected with the other cells through slightly protruding points of junction or short arms, and thus also form a net parallel to the thallus surface (Figure 8). The third cortical layer is made up of ovoid cells $(<50 \mu \mathrm{m}$ in diameter) that develop secondary pit-connections between each other and with cells of contiguous cortical cell layers (Figure 8). The fourth cor- tical layer is formed by rounded cells $(<30 \mu \mathrm{m}$ in diameter) that are compactly arranged and connected by secondary pit-connections (Figure 8). Finally, outer cortical cells (4-12 $\mu \mathrm{m}$ diameter in surface view) are polyhedral, irregular or ovoid in shape, highly pigmented, compactly arranged, and lack secondary pit-connections (Figures 8, 10). The medulla is lax, and consists of numerous filaments intermixed with stellate cells and is immersed in a gelatinous matrix (Figure 7). Medullary filaments are simple, made up of one or more cells, hyaline or, if they contain floridean starch, brownish. They are usually arranged parallel to the thallus surface and occasionally connect to both sides of the cortex. Stellate medullary cells are refractive, ganglionic, with a rounded body cell $(<50 \mu \mathrm{m}$ in diameter) and have radially situated arms $<450 \mu \mathrm{m}$ long (Figure 11). These cells are also interconnected, thereby forming a network, and can be also connected to medullary filaments or to inner cortical cells.

Reproductive structures Female gametophytes are non-procarpic. Carpogonial branch systems arise on cells of the inner cortex and develop towards the medulla, and consist of a rounded supporting cell $(<22 \mu \mathrm{m}$ in diameter) which bears both several subsidiary cells that are rounded when young but irregular in shape at maturity, and several three-celled carpogonial branches. After presumed fertilization, the supporting cell fuses with subsidiary cells (Figure 12) forming a stellate fusion cell ( $<95 \mu \mathrm{m}$ in diameter), from which connecting filaments are formed (Figure 13). Connecting filaments are hyaline, non-septate $(<2 \mathrm{~mm}$ in length and $2 \mu \mathrm{m}$ in width), branched, and slightly swollen at the end (Figure 14). Auxiliary cell systems ( $<35 \mu \mathrm{m}$ in diameter), situated on the inner cortical cells and developing towards the 


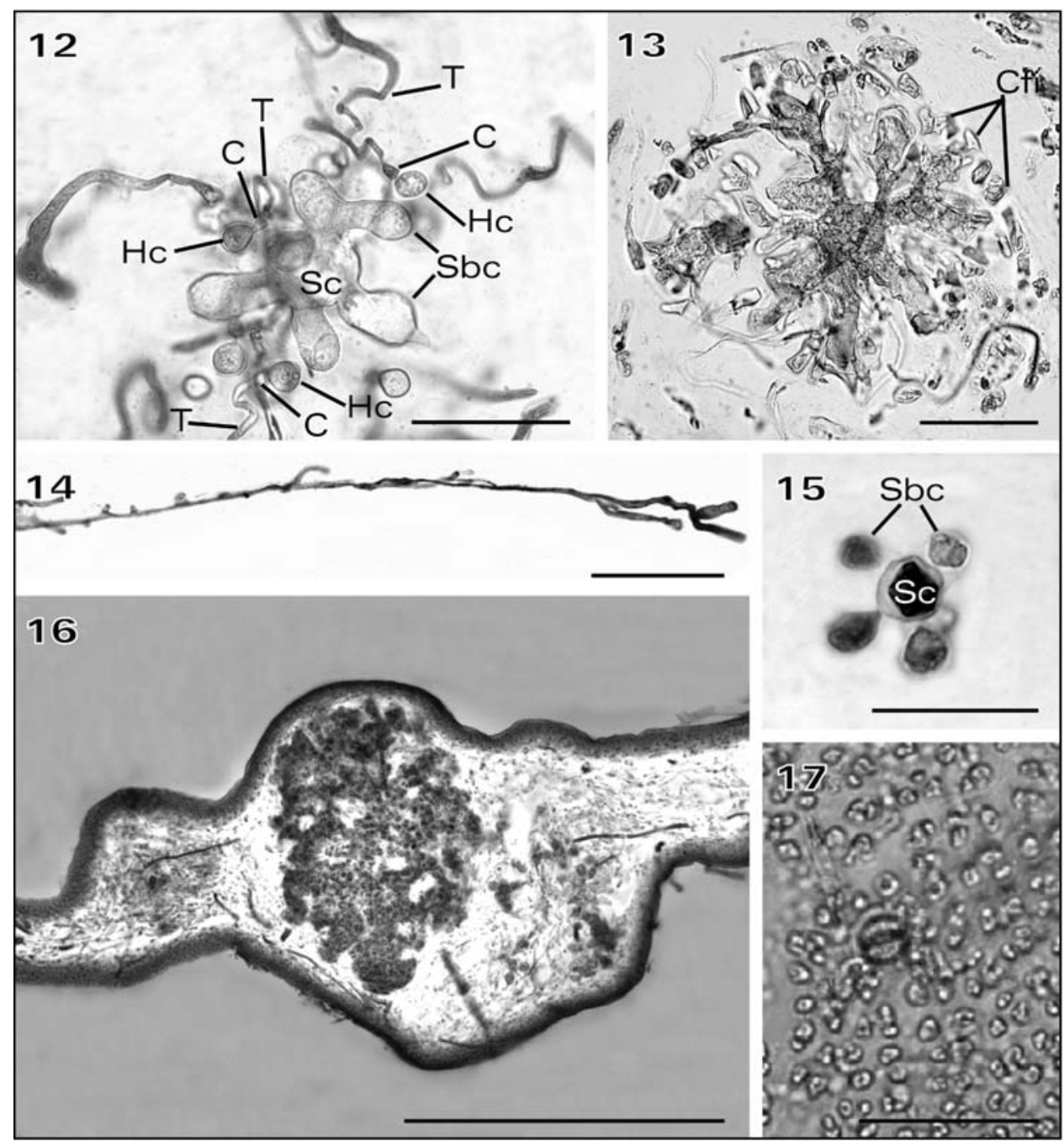

Figures 12-17 Kallymenia patens.

(12) Mature carpogonial cell system (C, carpogonium; Hc, hypogynous cell; Sc, supporting cell; Sbc, subsidiary cell; $\mathrm{T}$, trichogyne) (HGI-A 6469). (13) Fusion cell developing connecting filament initials (Cfi) (HGI-A 6469). (14) Apical part of a connecting filament (HGIA 6469). (15) Auxiliary cell system (HGl-A 6469). (16) Cross section of a mature gonimoblast (HGI-A 6469). (17) Sporangium on surface view (HGI-A 4749). Scale bars $=50 \mu \mathrm{m}$ (Figures 12-13, 17), $100 \mu \mathrm{m}$ (Figure 14), $25 \mu \mathrm{m}$ (Figure 15), $500 \mu \mathrm{m}$ (Figure 16).

medulla, are made up of a rounded or ovoid supporting cell that has up to 6 rounded subsidiary cells (Figure 15). We failed to observe either a connecting filament linked to the auxiliary cell system or the initial development of the gonimoblasts. Gonimoblasts ( $<570 \mu \mathrm{m}$ in diameter) grow on the small spathulate proliferations of perennial parts (Figures 4-6) through the medulla; they cause a swelling of the thallus (Figure 16) and they are surrounded by secondary vegetative filaments. An ostiole is absent, as carposporangia exit through the broken cortex. Carposporangia $(<15 \mu \mathrm{m}$ in diameter) usually germinate in situ. Fertile male gametophytes are unknown. Tetrasporophytes examined had immature tetrasporangia $(<14 \mu \mathrm{m}$ in diameter) scattered over the thallus in the outer cortex (Figure 17).

\section{Discussion}

The reproductive morphology of Kallymenia patens confirms its position, as postulated by Codomier (1971), in the genus Kallymenia. As in K. reniformis, the type spe- cies of the genus, $K$. patens is characterized reproductively by: (i) a trigenetic life history with isomorphic gametophytes and tetrasporophyte; (ii) a non-procarpic female reproductive apparatus; (iii) polycarpogonial branch systems made up of a rounded or lobed supporting cell that gives rise to one or several 3-celled carpogonial branches and some subsidiary cells; (iv) a fusion cell forming long and non-septate connecting filaments; (v) an auxiliary cell system made up of a supporting cell with several subsidiary cells around it; and (vi) a gonimoblast made up of carposporangia intermixed with gonimoblastic and vegetative filaments (Norris 1957, Codomier 1968, 1971, 1972, Hommersand and Ott 1970, Vergés 2001).

The vegetative morphology of Kallymenia patens was studied previously by J. Agardh (1851) and Codomier (1968, 1971, 1972). J. Agardh (1851) gave a detailed description of the morphology, which mostly corresponds to our observations, although he did not differentiate between young, old and fertile specimens. Our observations on vegetative morphology on $K$. patens agree with most of the features pointed out by Codomier 
(1968, 1971, 1972), except for the number of cortical layers of cells (3-5 in Codomier's vs. 5 in this study) and the length of all cortical cell layers (ccl), which is smaller in Codomier's surveys [First ccl: $35-40 \mu \mathrm{m}$, second ccl: 25-32 $\mu \mathrm{m}$, third ccl: 20-25 $\mu \mathrm{m}$, fourth ccl: 15-18 $\mu \mathrm{m}$, fifth ccl: 7-9 $\mu \mathrm{m}$, in Codomier's; first ccl: $40(-70) \mu \mathrm{m}$, second ccl: $46(-68) \mu \mathrm{m}$, third ccl: $33(-52) \mu \mathrm{m}$, fourth ccl: $16(-30) \mu \mathrm{m}$, fifth ccl: $7(-12) \mu \mathrm{m}$, in this study].

Perennial mature spathulated thalli of Kallymenia patens could be confused with small thalli of $K$. spathulata. To differentiate these species we examined the lectotype of $K$. spathulata (Marseille, Leg. A. Solier, LD 22382 sterile), four dried sheets (Marseille, Leg. A. Solier, LD 22383 sterile; $P$. and H. Huvé, 18 July 1953, H $3146 \oplus$; Marseille Gulf, Leg. P. and H. Huvé, 26 May 1955, 65 m, H 3147 sterile, H 3148 sterile) and two specimens collected in the Columbretes Islands, Spain (Columbrete Gran, Leg. E. Ballesteros, 22 June 1996, 44 m depth, HGI-A 3900, sterile; Columbrete Gran, Leg. C. Rodríguez-Prieto, 11 May 2002, 42 m deep HGI-A 5548, $\oplus$ ). Our observations showed that both species are perennial and form spathulated proliferations around the thallus, although in $K$. patens these are much shorter in length $(0.2-0.6 \mathrm{~cm})$ than in $K$. spathulata $(0.5-6.0 \mathrm{~cm})$. The vegetative structure is very similar in both species as they have: (i) a similar cross section $(150-250 \mu \mathrm{m}$ in $K$. patens and 180-300 $\mu \mathrm{m}$ in K. spathulata), (ii) five layers of cortical cells, (iii) compactly arranged outer cortical cells in surface view, and (iv) yellow medullary cells with a rounded body cell and radially arranged arms (Codomier 1968, 1971, 1972, Vergés 2001, this study). The main difference lies in the length of the inner cortical cells $(<70 \mu \mathrm{m}$ in $K$. patens and $<30 \mu \mathrm{m}$ in $K$. spathulata) and this is useful to distinguish them easily, as Codomier (1968, 1971, 1972) pointed out. With regard to reproductive morphology, although the gonimoblasts are located differently in each species, in $K$. patens they are grouped in small proliferations from the perennial part of the thallus and are $<600 \mu \mathrm{m}$ in diameter (this study), whereas in K. spathulata they extend all over the surface of the thallus and are $<300 \mu \mathrm{m}$ in diameter (Ercegovic 1949). Other reproductive characters cannot be compared as they remain unknown in $K$. spathulata.

In conclusion, we have confirmed the position of $\mathrm{Kal}-$ lymenia patens in the genus Kallymenia. Vegetative and reproductive morphologies of $K$. patens correspond to that of the type species $K$. reniformis. Comparison between $K$. patens and $K$. spathulata has shown several similarities but some clear differences that easily distinguish them, such as: (i) the maximum length of spathulated thallus proliferations, (ii) the length of inner cortical cells, and (iii) the location of the gonimoblasts.

\section{Acknowledgements}

We wish to thank the following people for the loan of valuable herbarium specimens: Marc Verlaque, for the materials from the $P$. and $H$. Huvé Herbarium housed at Verlaque Herbarium $(H)$ in the Centre d'Océanologie de Marseille; Susanna Riebe, for the specimens from the Herbarium of the Botanical Museum of
Sweden (LD); Fernando Boisset, for the specimens from the Herbarium of the University of Valencia (VAL); and Enric Ballesteros and Natàlia Sant, for recent collections from the Balearic Islands and the Columbretes Islands. We would also like to thank Pere Tur and Jordi Ros for accompanying us on dives, and two anonymous reviewers for improving the paper. This project was supported by a grant from the Spanish Ministry of Science and Technology (Flora Algológica de la Península lbérica y de las islas Baleares. Gigartinales, PB95-0385-C06-06).

\section{References}

Agardh, J.G. 1842. Algae maris Mediterranei et Adriatici, observationes in diagnosin specierum et dispositionem generum. Fortin, Masson et Cie, Parisiis [Paris]. pp. 164.

Agardh, J.G. 1851. Species genera et ordines algarum, seu descriptiones succinctae specierum, generum et ordinum, quibus Floridearum classis constitur. Vol. 2: Florideae, part 1. Malmström, Lundae [Lund]. pp. [i]-xii, [1]-351.

Codomier, L. 1968. Recherches sur les Kallymenia (Cryptonémiales) et sur quelques autres Rhodophycées foliacées de la Méditerranée. Thesis degree. University of Paris VI, France. pp. 288.

Codomier, L. 1971. Recherches sur les Kallymenia (Cryptonémiales, Kallymeniacées). I. Les espèces Méditerranéennes. Vie Milieu 22: 1-54.

Codomier, L. 1972. Recherches sur la reproduction, le cycle de vie et l'ontogenèse des Cryptonémiales et des Gigartinales méditerranéennes à thalle foliacé. PhD thesis. University of Paris VI, France. pp. 179.

Codomier, L. 1978. Recherches sur les Kallymenia (Cryptonémiales). III. Problèmes de la délimitation du genre Kallymenia. Rev. Algol. Nov. Ser. 13: 241-249.

DeToni, GB. 1905. Sylloge algarum omnium hucusque cognitarum. Vol. IV. Florideae. Sectio IV. Privately published, Patavii [Padova]. pp. [i-v], 1523-1973.

Ercegovic, A. 1949. Sur quelques algues rouges, rares ou nouvelles, de l'Adriatique. Acta Adriat. 4: 1-81.

Feldmann, J. 1942. Les Kallymenia (Rhodophycées, Cryptonémiales) des côtes d'Algérie. Bull. Soc. Hist. Nat. Afr. Nord 33: $7-14$.

Holmgren, P.K., N.H. Holmgren and I.C. Barnett. 1990. Index herbariorum. Part I. The herbaria of the world. Vol. 120. 8th edition. New York Botanical Garden, New York. pp. x, 693.

Hommersand, M.H. and D.W. Ott. 1970. Development of the carposporophyte of Kallymenia reniformis (Turner) J. Agardh. J. Phycol. 6: 322-331.

Norris, R.E. 1957. Morphological studies on the Kallymeniaceae. Univ. Calif. Publ. Bot. 28: 251-334.

Parkinson, P.G. 1980. Halymenia, being a critical account of the confused nomenclature of Halymenia C.A. Agardh 1817 (Halymeniaceae, Cryptonemiales, Rhodophyta) with reflections on the international code of botanical nomenclature and corrections to certain recent work in which it has been disregarded. Pettifogging Press, Auckland. pp. 1-20.

Rodríguez-Prieto, C. and A. Vergés. 2001. Geographical distribution, habitat and reproductive phenology of the genus $\mathrm{Kal}$ lymenia (Gigartinales, Rhodophyta) from Catalonia, Spain. Bot. Mar. 44: 479-492.

Vergés, A. 2001. El gènere Kallymenia (Kallymeniaceae, Rhodophyta) a la península Ibèrica $i$ illes Balears. PhD thesis. University of Girona, Spain. pp. 298.

Vergés, A. and C. Rodríguez-Prieto. 2006. Anatomical characteristics and reproductive structures of Kallymenia lacerata (Kallymeniaceae, Rhodophyta) from the Mediterranean Sea. Cryptogam., Algol. 27: 31-43.

Received 16 May, 2006; accepted 4 July, 2006 